\author{
Doroshenko D., \\ Pylypenko I., \\ Kornilovych B., \\ Subbota I.
}

\title{
PREPARATION OF POROUS SILICA NANOCOMPOSITES FROM MONTMORILLONITE USING SOL-GEL APPROACH
}

Об’єктом дослідження є монтморилоніт, який завдяки своїм властивостям і будові проявляє високі сорбційні характеристики. Однак суттєвою перешкодою його використання в промислових технологіях водоочищення є схильність монтморилоніту самочинно диспергуватись в водних розчинах на елементарні структурні пакети і утворювати стійкі зависі. Це призводить до виникнення складнощів при розділенні твердої і рідкої фаз після проведення процесу сорбиії. Авторами був використаний золь-гель метод синтезу нанокомпозитних матеріалів на основі монтморилоніту з використанням тетраетоксисилану в якості гелеутворюючої речовини. Синтез включає в себе реакцію гідролізу тетраетоксисилану і наступною поліконденсаиією молекул кремнекислоти з гідроксильними групами монтморилоніту. Отримані зразки поєднують в собі хороші сорбційні властивості шаруватого мінералу та міцну каркасну структуру. Така структура синтезованих нанокомпозитів забезпечується наявністю силоксанових зв'язків, якими елементарні пакети монтморилоніту з’єднані між собою. Це, в свою чергу, сприяє збільшенню водостійкості експериментальних зразків. Згідно з результатами реологічних досліджень, основні процеси структуроутворення у вихідних водно-спиртових суспензіях продуктів гідролізу тетраетоксисилану та монтморилоніту відбуваються при концентрації кремнезему $1 \%$, що пов'язано з колоїдно-хімічними властивостями досліджуваних систем. Обробка монтморилоніту продуктами гідролізу тетраетоксисилану приводить до утворення матеріалу з нижчою здатністю до набухання та кращим розділенням рідкої та твердої фаз. Оптимальний вміст кремнезему у зразку, який знаходиться в інтервалі 0,1-14 \%, дає змогу зменшити оптичну густину розчинів у 2,5 рази у порівнянні з вихідним монтморилонітом. Синтезовані матеріали зберігають достатньо високу сорбиійну ємність щодо вилучення катіонного барвника метиленового блакитного (до 158 мг/г), яка зростає при збільшенні вмісту глинистого мінералу. А також мають вищу селективність (до 3,4 дм /мг).

Ключові слова: золь-гель синтез, модифікація поверхні, ізотерма сорбцї, монтморилоніт, тетраетоксисилан, метиленовий блакитний.

\section{Introduction}

One of the most important problems of our time is the removal of toxicants of organic and inorganic origin (ions of heavy metals, dyes and other compounds) from the aquatic environment, which are in large quantities in industrial wastewater. When entering the hydrosphere, these toxicants adversely affect the living organisms of our planet, as well as the state of the terrestrial ecosystem as a whole.

When purifying industrial wastewater, or when obtaining drinking water from contaminated sources of water supply, sorption methods are indispensable. In recent decades, sorption studies of heavy and radioactive metals, as well as synthetic dyes of organic or inorganic origin in natural materials, for example, clay minerals (montmorillonite, kaolinite, illite, etc.) have been widely conducted. The latter are cheaper and easily accessible compared to much more expensive activated carbon or ion exchange resins, traditionally used in chemical technology.

Layered silicates are characterized by complex surface chemistry due to the presence of active centers of different nature. These may be hydroxyl groups on the side faces of the mineral, silanol groups in places of crystal defects on the basal surfaces of planar particles, nonstoichiometric isomorphous substitutions in the mineral structure, etc. Such set of active centers opens the possibility of applying many strategies for surface functionalization [1].

Therefore, research in this area should be considered relevant, namely, the search for new methods for modifying the surface of clay minerals to obtain modern effective sorption materials, but with the condition that the economic expediency of producing such sorbents is preserved.

\section{The object of research and its technological audit}

The object of research is montmorillonite. This is a natural layered silicate with structural packets of type $2: 1$, in which one layer of alumina octahedra is located between two layers of siliceous tetrahedra.

Among other natural clay minerals, montmorillonite is characterized by a large specific surface area, as well as high values of cation exchange capacity. However, technological audit indicates that the obstacle for its wide application in water treatment technologies is the ability of clay minerals to disperse in an aqueous medium with the formation of stable slurry. As a result, after the sorption processes, difficulties arise with the separation of the liquid and solid phases. 


\section{The aim and objectives of research}

The aim of research is studying the structural and sorption characteristics of a synthesized semi-synthetic nanocomposite material.

To achieve this aim, it is necessary to perform the following tasks:

1. Synthesize experimental samples by modifying the montmorillonite surface with sol-gel method using tetraethoxysilane (TEOS) as a structurant reagent and investigating the rheological properties of the initial systems, as well as the structure formation processes in them, depending on the silica content.

2. Determine the effect of the composition of nanocomposites on the sorption properties with respect to the cationic dye of methylene blue.

3. Determine the effect of the composition of the material on the value of the separation index of the solid and liquid phases.

\section{Research of existing solutions of the problem}

Recently, much attention has been paid to studying the methods of structural modification of clay minerals as promising sites for the creation of catalysts or adsorbents for various purposes. Both surface-layered and layered minerals (montmorillonite, saponite, kaolinite) are used to modify the surface, the structural features of which determine the usefulness of the method of modification.

In particular, montmorillonite, due to its developed specific surface and sufficiently high cation-exchange capacity (up to $120-140 \mathrm{mmol} / \mathrm{g}$ ), due to the presence of nonstoichiometric isomorphic substitutions in the structure, is often chosen as an object of additional modification. Among such methods, mechanochemical or hydrothermal treatment is isolated during which the structure of the mineral is partially destroyed and new active centers appear $[2,3]$.

Acid activation also makes it possible to improve certain properties of clay minerals. For example, the interaction of montmorillonite with concentrated sulfuric acid leads to leaching of aluminum from the octahedral layer and improvement of the pore structure of the resulting material, which in turn improves sorption properties [4].

A separate method of structural modification is the pillaring based on intercalation of the polynuclear cationic hydroxocomplexes of metals to the interlayer space of layered aluminosilicates with subsequent heat treatment. Such materials have an increased specific surface area, they do not swell in aqueous solutions and can selectively remove inorganic and organic toxicants of aqueous solutions [5-7].

Cationic surfactants are often used to modify the surface of clay minerals. Positively charged surfactant molecules replace exchange cations in interlayer space and on the surface of the mineral, creating a hydrophobic layer or a positively charged bi-layer, which allows the removal of anionic dyes from aqueous solutions [8, 9].

The presence of hydroxyl groups $(\equiv \mathrm{Si}-\mathrm{OH}$ and $=\mathrm{Al}-\mathrm{OH})$ on the side surfaces of the mineral particles makes it possible to carry out their additional functionalization due to the formation of chemically bound molecules on the surface of the mineral. Such reagents include $\gamma$-aminopropyltriethoxysilane and its derivatives, which make it possible to obtain highly selective sorption materials to extract, as a rule, anionic toxicants [10-12].

Composite sorption materials, which include not only clay minerals but also other components, for example, metal hydroxides, activated carbon, ion exchange resins, are also quite common [13].

Silica gel and other silica derivatives have found wide application in sorption processes [14]. The preparation of composite materials based on clay minerals together with silica opens the way to obtaining new functional materials, which is the aim of this work.

To modify the surface of montmorillonite, a rather simple and cheap reagent, sodium silicate, was previously used [15]. The obtained composite material is characterized by sufficiently high sorption characteristics. However, when using tetraethoxysilane (TEOS) as a modifier, it is likely to produce composite materials with better properties, since TEOS hydrolysis processes result in the formation of silicic and polysilicic acids of low molecular weight. The latter have an increased reactivity compared to the large molecules of silicic acid formed by the use of sodium silicate [16]

\section{Methods of research}

Homogenization of sodium montmorillonite (Na-MMT) suspensions for synthesis was carried out using ultrasonic disperser УЗДН-2Т (Ukraine). X-ray diffraction patterns were obtained with а ДРОН 4-07 diffractometer (USSR) with $\mathrm{Cu} \mathrm{K \alpha}$ radiation $(\lambda=0.154 \mathrm{~nm}, 35 \mathrm{kV}, 30 \mathrm{~mA})$ at $25{ }^{\circ} \mathrm{C}$ in the $2 \theta$ range from 3 to $40^{\circ}$.

The rheological data were obtained with a Rheotest-2 rotary viscosimeter (Germany) at $25^{\circ} \mathrm{C}$, and the experimental data were processed using the Bingham-Shvedov equation, which allows one to characterize the dispersion of clay minerals. The Bingham-Shvedov equation has the form [17]:

$$
\tau=\tau_{0}+\eta \cdot D
$$

where $D$ - strain rate; $\tau$ and $\tau_{0}-$ stress and limiting shear stress respectively; $\eta$ - plastic viscosity.

The sorption properties of the samples were studied with the sorption of the cationic dye - methylene blue under static conditions, the concentration of which was determined spectrophotometrically using a UNICO-UV 2100 spectrophotometer (USA) at a wavelength of $665 \mathrm{~nm}$. The weight of the adsorbent was $0.1 \mathrm{~g}$ per $50 \mathrm{~cm}^{3}$ solution. The selected duration of contact between the solid and liquid phases was one hour, which corresponds to the establishment of adsorption equilibrium.

Determination of the optical density of the solutions was carried out according to the following procedure. A $0.1 \mathrm{~g}$ sample of sorbent was introduced into a conical flask of $100 \mathrm{~cm}^{3}$ and $50 \mathrm{~cm}^{3}$ of a $0.1 \mathrm{M} \mathrm{NaCl}$ solution was added and the flasks were shaken on the shaker for $60 \mathrm{~min}$. The contents of the flasks were transferred into beakers per $100 \mathrm{~cm}^{3}$, and after settling for 10 minutes, solution was decanted with following measurement of its optical density at a wavelength of $400 \mathrm{~nm}$ and a cell length of $1 \mathrm{~cm} .0 .1 \mathrm{M} \mathrm{NaCl}$ was the reference solution.

To study the effect of the TEOS content of structural and sorption properties, a synthesis of experimental samples with different ratios Na-MMT/TEOS $/\left(\mathrm{H}_{2} \mathrm{O}+\mathrm{C}_{2} \mathrm{H}_{5} \mathrm{OH}\right)$ was carried out. The list of samples obtained is shown in Table 1. 
Table 1

Composition of the obtained samples

\begin{tabular}{|c|c|c|c|c|c|c|}
\hline \multirow{2}{*}{$\begin{array}{c}\text { No. of } \\
\text { sample }\end{array}$} & \multicolumn{5}{|c|}{ Bulk content, \% } \\
\cline { 2 - 7 } & Na-MMT & TEOS $\left(\mathrm{SiO}_{2}\right)$ & $\mathrm{H}_{2} \mathrm{O}$ & $\mathrm{C}_{2} \mathrm{H}_{5} \mathrm{OH}$ & Na-MMT & $5 \mathrm{Si}_{2}$ \\
\hline 1 & 3 & 0 & 97 & 0 & 100 & 0 \\
\hline 2 & 3 & 0.1 & 38.7 & 58.1 & 97 & 3 \\
\hline 3 & 3 & 0.5 & 38.6 & 57.9 & 86 & 14 \\
\hline 4 & 3 & 1 & 38.4 & 57.6 & 75 & 25 \\
\hline 5 & 3 & 2 & 38 & 57 & 60 & 40 \\
\hline 6 & 3 & 4 & 37.2 & 55.8 & 43 & 57 \\
\hline 7 & 3 & 10 & 34.8 & 52.2 & 23 & 77 \\
\hline
\end{tabular}

To prepare samples of the composite with an aqueous suspension of montmorillonite pretreated for 5 minutes with an ultrasonic dispersant, an appropriate amount of TEOS and ethanol was added, and the obtained mixture was treated with an ultrasonic disperser for 1 minute. After that, the $\mathrm{pH}$ of the mixture was adjusted to level 2 with sulfuric acid followed by ultrasonic treatment for 1 minute. After TEOS hydrolysis, the mixture was transferred to a magnetic stirrer, the $\mathrm{pH}$ was adjusted to 7 with sodium hydroxide solution and, with vigorous stirring under heating $\left(60{ }^{\circ} \mathrm{C}\right)$, the mixture was held for hours. The resulting suspension was transferred to an evaporation bowl, held for 48 hours at $25{ }^{\circ} \mathrm{C}$ to complete gelation, washed from the salts with a $60 \%$ ethanol solution in a vacuum filter and dried at $105{ }^{\circ} \mathrm{C}$ to constant weight. At the final stage, the sample was ground, screened and a fraction of 0.063-0.16 mm was selected for further studies. Samples for rheological studies were selected at the synthesis stage, after the addition of sodium hydroxide solution.

\section{Research results}

The processes of structure formation in dispersions of montmorillonite with TEOS in aqueous media with a high content of ethanol proceed by a different mechanism than sodium silicate in water [15]. Rheological studies have shown that the curves for the flow of such dispersions (Fig. 1, $a$ ) have a less pronounced tendency to form hysteresis loops, indicating that there is practically no thixotropic properties in them. Such changes are due to a lower polarity of ethanol, enters into reaction mixtures with TEOS compared to water (ethanol dielectric constant - 24.6, water - 81.0). Replacing part of the water with ethanol leads to a decrease in the intensity of interaction between the molecules of the dispersion medium and the particles of the dispersed phase. According to the data $[18,19]$, in solutions of ethanol or other alcohols, the self-dispersion of clay minerals is poorly expressed, which causes a decrease in the volume concentration of the dispersed phase.

In addition, there is a decrease in the values of the limiting shear stress and plastic viscosity. This is due to the fact that during the TEOS hydrolysis, in an acidic environment, in contrast to sodium silicate, polycondensation processes predominate with the formation of low molecular weight silicic and polysilicic acids that have an increased reactivity.
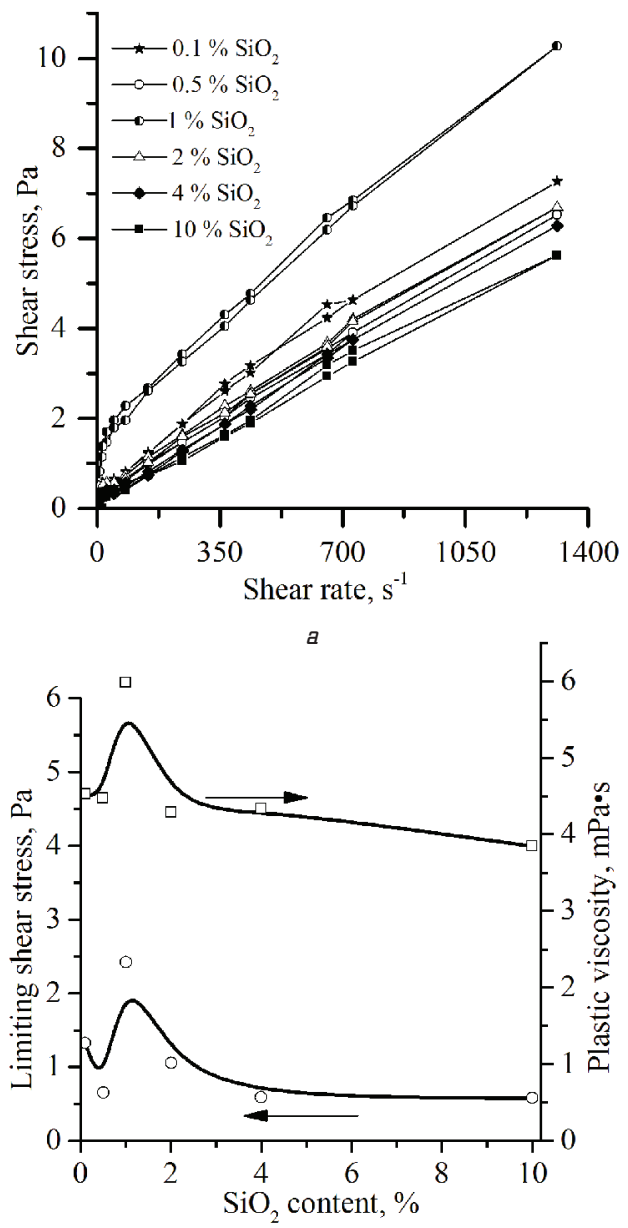

$b$

Fig. 1. Rheological studies of experimental samples: a - flow curves of suspensions of montmorillonite with different silica content; $b$ - dependence of the limiting shear stress and plastic viscosity on the silica content

These silicic acid molecules interact predominantly with hydroxyl groups of the edge surface of montmorillonite $(\equiv \mathrm{Si}-\mathrm{OH})$ due to polycondensation reactions [16]. The maxima on the curves of the limiting shear stress and plastic viscosity at a $1 \%$ silica content (Fig. 1, b) correspond to the formation of the maximum amount of silica nanoparticles on the surface of clay particles. The latter are combined with each other due to interaction with the «side surface - silica globule - lateral surface» scheme. In most cases, the formation of low-order «house of cards» structures, in which clay mineral particles are placed chaotically, is most likely [20]. When the TEOS content in the system increases, silica globule grows, which is accompanied by an increase in internal stresses in the existing coagulation-condensation structure and, correspondingly, a decrease in its strength.

This interpretation of the results is confirmed by electron microscopy and X-ray analysis. Diffractograms of nanocomposite samples (Fig. 2) indicate a gradual decrease in the intensity of the basal reflex of montmorillonite $(1.26 \mathrm{~nm})$ with increasing silica content. For the raw montmorillonite (curve $100 \%$ ), the basal reflex is most clearly expressed. For pure silica (curve $0 \%$ ), the diffractograms have no pronounced reflexes, except two at 27 and $31 \cdot 2 \Theta$. The latter may belong to the residues of sodium sulphate, which is formed during the synthesis of samples and is 
difficult to remove from the samples. The decrease in the intensity of the basal reflex of montmorillonite indicates a gradual transition of the system to a less ordered state with a chaotic arrangement of the mineral particles. In addition, a decrease in the mass fraction of montmorillonite in nanocomposites can also reduce the intensity of the reflex, since the fraction of one of the crystalline phases is decreased.

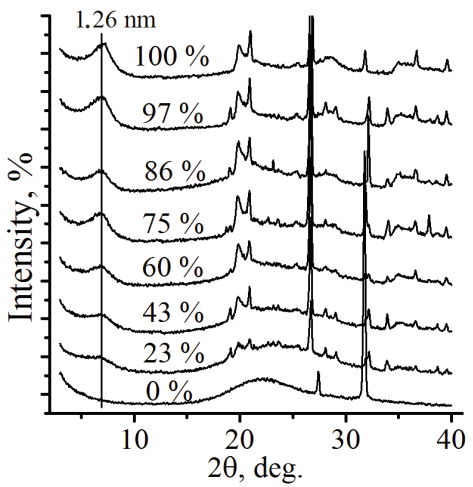

Fig. 2. Diffractograms of samples of nanocomposites with different contents of montmorillonite

The sorption capacity of nanocomposites was studied by the sorption of methylene blue (MB) (Fig. 3), one of the most common organic dyes in wastewater from industrial enterprises [21].<smiles>CN(C)c1ccc2nc3ccc(=[N+](C)C)cc-3sc2c1</smiles>

Fig. 3. Structural formula of methylene blue

In chemistry of clay minerals, MB is also used as a standard reagent to determine the characteristics of the surface. Specific surface of the samples $\left(\mathrm{m}^{2} / \mathrm{g}\right)$ was determined by the formula [22]:

$$
S_{s p .}=a_{\infty} \cdot N_{A} \cdot s_{m},
$$

where $a_{\infty}$ - the capacity of the monolayer (limiting adsorption) $\mathrm{mol} / \mathrm{g} ; N_{A}-$ Avogadro number $\left(\mathrm{mol}^{-1}\right) ; s_{m}-$ the area occupied by one MB molecule on the surface $\left(75 \AA^{2}\right)$.

Isotherms of $\mathrm{MB}$ sorption with nanocomposite samples are shown in Fig. 4.

The experimental data are described quite well by the Langmuir equation with correlation coefficients from 0.934 to 0.998 (Table 2).

This dependence is primarily due to the suppressive sorption of MB ions by the surface of a clay mineral - at cation exchange centers (approximately equal in energy), while the silica phases contribute insignificantly to the total MB sorption. This is also confirmed somewhat lower by the values of the correlation coefficients according to the Freundlich model $(0.817-0.984)$. An increase in the silica content leads to a decrease in the sorption capacity, which is due to the covering of the cation exchange centers by globules of silica gel on the basal surface of montmorillonite.

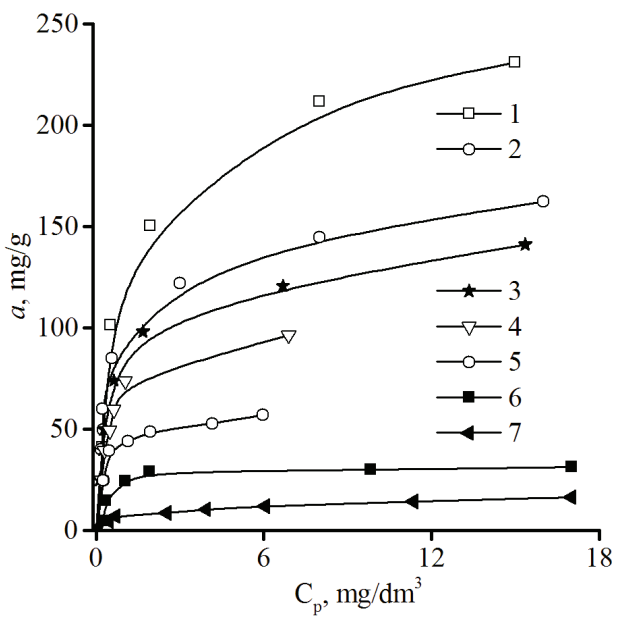

Fig. 4. Sorption isotherms of methylene blue on nanocomposite samples with different silica content (Table 1)

Table 2

The coefficients of the adsorption equations of methylene blue on nanocomposite samples at $\mathrm{pH} 6$

\begin{tabular}{|c|c|c|c|c|c|c|c|}
\hline \multirow{2}{*}{ Sample } & \multicolumn{2}{|c|}{$\begin{array}{c}\text { According to the } \\
\text { Freundlich }\end{array}$} & \multicolumn{4}{c|}{ According to the Langmuir } \\
\cline { 2 - 8 } & $K_{F}$ & $1 / n$ & $R^{2}$ & $K_{L} \mathrm{dm}^{3} / \mathrm{mg}$ & $a_{\infty}, \mathrm{mg} / \mathrm{g}$ & $R^{2}$ & $S_{s p,} \mathrm{~m}^{2} / 9$ \\
\hline $\mathrm{Na}-\mathrm{MMT}$ & 110.07 & 3.4 & 0.937 & 1.10 & 238.0 & 0.981 & 336.0 \\
\hline $0.1 \% \mathrm{SiO}_{2}$ & 78.67 & 3.5 & 0.908 & 1.70 & 158.5 & 0.934 & 223.7 \\
\hline $0.5 \% \mathrm{SiO}_{2}$ & 70.56 & 4.0 & 0.929 & 1.95 & 130.3 & 0.998 & 183.9 \\
\hline $1 \% \mathrm{SiO}_{2}$ & 59.97 & 3.6 & 0.927 & 1.95 & 105.4 & 0.994 & 148.7 \\
\hline $2 \% \mathrm{SiO}_{2}$ & 40.83 & 5.0 & 0.969 & 3.43 & 57.6 & 0.987 & 81.3 \\
\hline $4 \% \mathrm{SiO}_{2}$ & 19.04 & 4.9 & 0.817 & 1.88 & 33.3 & 0.940 & 46.8 \\
\hline $10 \mathrm{SiO}_{2}$ & 7.26 & 3.7 & 0.984 & 0.46 & 17.9 & 0.939 & 25.3 \\
\hline
\end{tabular}

It has been established that the values of limiting adsorption, as well as the calculated specific surface, for MB are reduced in the concentration range $0-3 \%$ after silica (Table 2). A further increase in the $\mathrm{SiO}_{2}$ content has little effect on the value of the limiting adsorption. This dependence may indicate the formation of the basic structure of the nanocomposite at silica concentrations of up to $3 \%$. A further increase in the silica content leads to precipitation of the latter on the free surface of the composite, which has little effect on the value of the limiting adsorption. Sufficiently high values of the limiting $\mathrm{MB}$ adsorption in the range $0-0.5 \% \mathrm{SiO}_{2}$ are related, first of all, to the $\mathrm{MB}$ dimerization. The molecules (ions) of methylene blue, both in solutions and on the surface, are characterized by the formation of dimers even at concentrations of $2 \mathrm{mg} / \mathrm{dm}^{3}$ [23], and increasing the ionic strength of the solution increases the content of dimers [24].

To determine the effectiveness of synthesized nanocomposites for use in sorption technologies, the optical density of solutions was studied after their contact with 
the adsorbent. This value is proportional to the concentration of the dispersed phase in the solution and can serve to evaluate the efficiency of phase separation after the sorption process.

The results show that nanocomposites have a much higher separation index, lower swelling capacity and are more easily separated from aqueous solutions, unlike the original montmorillonite. The change in the optical density of the solutions with 1.64 for the original montmorillonite at 0.069 for the sample with $23 \%$ montmorillonite (Fig. 5) indicates the formation of sufficiently strong aggregates from the sorbent particles after the TEOS treatment.

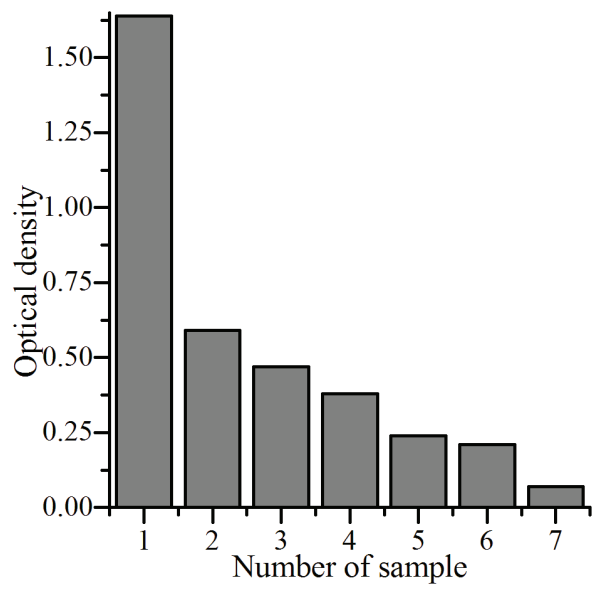

Fig. 5. Optical density of solutions after contact with samples of nanocomposites

There is a sharp (2.5 times) decrease in optical density, even with a small amount (3\%) of silica in the sample. Thus, treatment of montmorillonite with even a small amount of TEOS (from $3 \%$ by weight) allows a significant increase in the separation index.

The obtained results indicate the prospect of development for extraction of cationic dyes from aqueous solutions of sorption materials based on cheap natural raw material montmorillonite and the available silica compound - tetraethoxysilane. At the same time, using even a small amount of the latter, it is possible to obtain economically advantageous semisynthetic sorbents.

\section{SWOT analysis of research results}

Strengths. The main advantage of such sorption materials is low cost and environmental friendliness, since the main component is a natural mineral, whose reserves in Ukraine are quite large. Similar sorption materials are often obtained using rather expensive reagents and sophisticated hardware design of technologies, significantly increases their cost price.

Weaknesses. The use of tetraethoxysilane and ethanol as reagents for synthesis significantly increases the cost of the material.

Opportunities. A promising direction for further research is the development of a technology for granulating the nanocomposite obtained and investigating the possible replacement of valuable tetraethoxysilane and ethanol with cheaper analogues.

Threats. Availability of sufficiently effective sorption materials on the world market based on activated carbon or ion-exchange resins creates a sufficiently strong competitive environment.

\section{Conclusions}

1. The rheological properties of the initial systems based on the products of the hydrolysis of tetraethoxysilane and montmorillonite in water-ethanol media were investigated. It has been established that the maxima on the curves of the limiting shear stress and plastic viscosity are observed with a content of $1 \%$ silica in the samples.

2. It is established that the sorption properties with respect to the cationic methylene blue dye depend significantly on the composition of the nanocomposites. It is shown that the limiting adsorption increases monotonically with increasing montmorillonite content. Taking into account other parameters, the optimum silica content in dry nanocomposites is in the range of 3-14\%.

3. It is found that the minimum silica content, which provides an effective separation of the solid and liquid phases after the sorption process, is $0.5 \% \mathrm{SiO}_{2}$ in the system, or $14 \%$ in terms of the dry sample.

\section{References}

1. Uddin M. K. A review on the adsorption of heavy metals by clay minerals, $\mathrm{T}$ with special focus on the past decade // Chemical Engineering Journal. 2017. Vol. 308. P. 438-462. doi: http://doi.org/10.1016/j.cej.2016.09.029

2. Tian G. et. al. Ammonium sulfide-assisted hydrothermal activation of palygorskite for enhanced adsorption of methyl violet // Journal of Environmental Sciences. 2016. Vol. 41. P. 33-43. doi: http://doi.org/10.1016/j.jes.2015.03.036

3. Petra L. et. al. Mechanochemically activated saponite as materials for $\mathrm{Cu} 2+$ and $\mathrm{Ni} 2+$ removal from aqueous solutions // Applied Clay Science. 2017. Vol. 143. P. 22-28. doi: http:// doi.org/10.1016/j.clay.2017.03.012

4. Cakmak M. et. al. Removal of astrazon golden yellow 7GL from colored wastewater using chemically modified clay // Journal of Central South University. 2017. Vol. 24, Issue 4. P. 743-753. doi: http://doi.org/10.1007/s11771-017-3476-y

5. Huang W. et. al. Effective phosphate adsorption by $\mathrm{Zr} / \mathrm{Al}$ pillared montmorillonite: insight into equilibrium, kinetics and thermodynamics // Applied Clay Science. 2015. Vol. 104 P. 252-260. doi: http://doi.org/10.1016/j.clay.2014.12.002

6. Pylypenko I. V., Kornilovych B. Y., Kovalchuk I. A. Synthesis and sorption properties of $\mathrm{Ti}$ - and $\mathrm{Ti} / \mathrm{Al}$-pillared montmorillonite // Himia, Fizika Ta Tehnologia Poverhni. 2015. Vol. 6, Issue 3. P. 336-342. doi: http://doi.org/10.15407/hftp06.03.336

7. Zhang $\mathrm{S}$. et. al. Removal of fluoride ion from groundwater by adsorption on lanthanum and aluminum loaded clay adsorbent // Environmental Earth Sciences. 2016. Vol. 75, Issue 5. P. 401. doi: http://doi.org/10.1007/s12665-015-5205-x

8. Anirudhan T. S., Ramachandran M. Adsorptive removal of basic dyes from aqueous solutions by surfactant modified bentonite clay (organoclay): kinetic and competitive adsorption isotherm // Process Safety and Environmental Protection. 2015. Vol. 95 P. 215-225. doi: http://doi.org/10.1016/j.psep.2015.03.003

9. Omorogie M. O. et. al. The sequestral capture of fluoride, nitrate and phosphate by metal-doped and surfactant-modified hybrid clay materials // Chemical Papers. 2018. Vol. 72, Issue 2. P. 409-417. doi: http://doi.org/10.1007/s11696-017-0290-9

10. Xue A. et. al. Adsorption of reactive dyes from aqueous solution by silylated palygorskite // Applied Clay Science. 2010. Vol. 48. Issue 4. P. 638-640. doi: http://doi.org/10.1016/j.clay.2010.03.011

11. Moreira M. A. et. al. Effect of chemical modification of palygorskite and sepiolite by 3-aminopropyltriethoxisilane on adsorption of cationic and anionic dyes // Applied Clay Science. 2017. Vol. 135. P. 394-404. doi: http://doi.org/10.1016/j.clay.2016.10.022

12. Thue P. S. et. al. Synthesis and characterization of a novel organic-inorganic hybrid clay adsorbent for the removal of acid 
red 1 and acid green 25 from aqueous solutions // Journal of Cleaner Production. 2018. Vol. 171. P. 30-44. doi: http:// doi.org/10.1016/j.jclepro.2017.09.278

13. Pawar R. R. et. al. Efficient removal of hazardous lead, cadmium, and arsenic from aqueous environment by iron oxide modified clay-activated carbon composite beads // Applied Clay Science. 2018. Vol. 162. P. 339-350. doi: http://doi.org/ 10.1016/j.clay.2018.06.014

14. Diagboya P. N. E., Dikio E. D. Silica-based mesoporous materials; emerging designer adsorbents for aqueous pollutants removal and water treatment // Microporous and Mesoporous Materials. 2018. Vol. 266. P. 252-267. doi: http://doi.org/ 10.1016/j.micromeso.2018.03.008

15. Doroshenko D., Pylypenko I., Kornilovych B. Sorption of cobalt and methylene blue ions by montmorillonite-silica nanocomposites // KPI Science News. 2018. Vol. 3. P. 7-14. doi: http:// doi.org/10.20535/1810-0546.2018.3.126410

16. Qian Z. et. al. Preparation and characterization of montmorillonitesilica nanocomposites: A sol-gel approach to modifying clay surfaces // Physica B: Condensed Matter. 2008. Vol. 403, Issue 18. P. 3231-3238. doi: http://doi.org/10.1016/j.physb.2008.04.008

17. Shramm G. Osnovy prakticheskoy reologii i reometrii. Moscow: KolosS, 2003. 312 p.

18. Kimura Y., Haraguchi K. Clay-alcohol-water dispersions: anomalous viscosity changes due to network formation of clay nanosheets induced by alcohol clustering // Langmuir. 2017. Vol. 33, Issue 19. P. 4758-4768. doi: http://doi.org/10.1021/acs.langmuir.7b00764

19. Chen T., Zhao Y., Song S. Comparison of colloidal stability of montmorillonite dispersion in aqueous $\mathrm{NaCl}$ solution with in alcohol-water mixture // Powder Technology. 2017. Vol. 322. P. 378-385. doi: http://doi.org/10.1016/j.powtec.2017.09.032

20. Bi W. et. al. In situ synthesis of silica gel nanowire/Na+-montmorillonite nanocomposites by the sol-gel route // Nanotechnology. 2007. Vol. 18, Issue 11. P. 115620. doi: http://doi.org/ 10.1088/0957-4484/18/11/115620

21. Ngulube T. et. al. An update on synthetic dyes adsorption onto clay based minerals: A state-of-art review // Journal of
Environmental Management. 2017. Vol. 191. P. 35-57. doi: http:// doi.org/10.1016/j.jenvman.2016.12.031

22. Hegyesi N., Vad R. T., Pukanszky B. Determination of the specific surface area of layered silicates by methylene blue adsorption: The role of structure, $\mathrm{pH}$ and layer charge // Applied Clay Science. 2017. Vol. 146. P. 50-55. doi: http://doi.org/ 10.1016/j.clay.2017.05.007

23. Florence N., Naorem H. Dimerization of methylene blue in aqueous and mixed aqueous organic solvent: A spectroscopic study // Journal of Molecular Liquids. 2014. Vol. 198. P. 255-258. doi: http://doi.org/10.1016/j.molliq.2014.06.030

24. Mukherjee K. et. al. Adsorption enhancement of methylene blue dye at kaolinite clay-water interface influenced by electrolyte solutions // RSC Advances. 2015. Vol. 5, Issue 39 P. 30654-30659. doi: http://doi.org/10.1039/c5ra03534a

Doroshenko Dmytro, Postgraduate Student, Department of Chemical Technology of Ceramics and Glass, National Technical University of Ukraine «Igor Sikorsky Kyiv Polytechnic Institute», Ukraine, e-mail: doroshenko_dima@ukr.net, ORCID: http://orcid.org/00000002-1024-2279

Pylypenko Igor, PhD, Assistant, Department of Chemical Technology of Ceramics and Glass, National Technical University of Ukraine «Igor Sikorsky Kyiv Polytechnic Institute», Ukraine, e-mail: i.pylypenko@kpi.ua,ORCID: http://orcid.org/0000-0002-0236-7266

Kornilovych Borys, Doctor of Chemical Sciences, Professor, Corresponding Member of NAS Ukraine, Head of Department, Department of Chemical Technology of Ceramics and Glass, National Technical University of Ukraine «Igor Sikorsky Kyiv Polytechnic Institute», Ukraine, e-mail: b_kornilovych@kpi.ua, ORCID: http:// orcid.org/0000-0002-6393-6880

Subbota Irina, PhD, Associate Professor, Department of Chemical Technology of Ceramics and Glass, National Technical University of Ukraine «Igor Sikorsky Kyiv Polytechnic Institute», Ukraine, e-mail: i.subota@kpi.ua, ORCID: https://orcid.org/0000-0002-1581-8513 